Original Research Paper

\title{
The Republic of Kazakhstan Budget System Development and the Increase of its Transparency
}

\author{
${ }^{1}$ Kuralay Berkinovna Issatayeva and ${ }^{2}$ Ainagul Amangeldinovna Adambekova \\ ${ }^{I}$ U.U. Uspanov Kazakh Research Institute of Soil Science and Agrochemistry, Almaty, Kazakhstan \\ ${ }^{2}$ Turar Ryskulov New Economic University, School of Finance and Accounting, Almaty, Kazakhstan
}

\author{
Article history \\ Received: 18-11-2015 \\ Revised: 22-01-2016 \\ Accepted: 30-03-2016 \\ Corresponding Author: \\ Kuralay Berkinovna Issatayeva \\ U.U. Uspanov Kazakh \\ Research Institute of Soil \\ Science and Agrochemistry, \\ Almaty, Kazakhstan \\ Email: pohwabuh@mail.ru
}

\begin{abstract}
The article discusses the Republic of Kazakhstan's budget system development and the increase of its transparency compared with other countries. The history of the budget legislation for the Republic of Kazakhstan as an independent state began with the Declaration of State Sovereignty and the Law "On the Budget System" dated 17 December 1991, the first document, which modeled the principles of the budgetary system and budgetary process of a sovereign republic by law. Using the Republic of Kazakhstan as an example, the budget system development and ways to improve its efficiency and transparency were analyzed in this study. More openness and transparency of the budget system becomes extremely urgent task in connection with all the greater focus of public finances to address specific tasks to achieve the objectives of social and economic development. The paper deals with the openness of the budget of the Republic of Kazakhstan. In 2012, it stepped out of the category of the countries that provide minimal information on the budget. The aim of this study is to investigate the causes of the low transparency of the budget in Kazakhstan that in 2012 the International Budget Partnership (IBP) rated 48 (above the average of the countries) and to make suggestions to improve the transparency of the budget, which will lead to the improvement of living standards, reduction of corruption and improvement of the efficiency of budget spending.
\end{abstract}

Keywords: Kazakhstan, Budget System, Efficiency, Transparency

\section{Introduction}

The economy of any country cannot develop without defining its purpose. Defining goals is one of the main functions of the economic policy of Kazakhstan, which is based on macro-economic policies aimed at solving the major problems of national policy. Macroeconomic policy is a government action aimed at regulating the economy in order to maintain the pace of its full employment growth and curb inflation.

Budget financing should help accelerate the development of certain sectors of economy, create preconditions for the emergence of new industries and modern technology, acceleration of scientific and technological progress and provide conditions for the development of infrastructure industries (Zhunusova et al., 2014).

In terms of accelerating socio-economic development and globalization in the early twentieth century, a definition of the problem in the Republic of
Kazakhstan is that it faces certain difficulties caused by these processes. New conditions required the continued development of the Kazakhstani budget system and budgeting models used around the world that are focused on results.

During the period of independent development the Kazakhstan budget system has undergone significant changes (LBS, 1991). On December 17, 1991 the first law "On the Budget System" was signed, which defined the budgetary structure of Kazakhstan. Its basic idea was to give independence to the most important sectors of the budget system: Government budget and local budget. Budget unanimity for different levels had not been established by law (LBS, 1991). Changes in the economic and political spheres, associated with the transition to a market economy and the adoption of the new Constitution dated August 30, 1995, including the implementation of the new tax legislation in 1995 (CRK, 1995), as well as the creation of the Treasury, motivated a prearrangement of the Law "On the Budget 
System" in 1996 (LBS, 1996). The law stipulated the principles of the budget system, regulated the preparation procedures, budget reviewing and approving system, as well as implementation and its monitoring. New concepts were introduced: Governmental grants, aid grants, transfers of authority, state guarantees, loans, borrowing and debts, government and local executive power stocks. Legally, public revenues are divided into national taxes, dues and fees, payments, local rates and charges. Since 1998 direct borrowings from the National Bank have been stopped (BCRK, 2005).

In 1997, a new budget classification for incomes and expenses was introduced, which made it possible to interconnect budget expenses with program implementation.

In April 1999, the third law "On the Budget System" was adopted. Income distribution common for all regions was introduced and a mechanism for budgetary penalization and governmental grants was established to assure equation of the local budgets (LBS, 1999). The distribution of revenues between the government and local budgets by types of income was conducted; government functions, funded respectively from the government and local budgets, were distinguished. It was defined that the local budget balance will be based on long-term amounts of recognized transfers between the government and local budgets. State non-budgeted funds were consolidated into the government budget. The reorganization of the Agency for Strategic Planning, the Ministry of Economy and Trade, the Ministry of State Revenue and the Ministry of Finance into the Ministry of Economic Affairs and Budget Planning of the Ministry of Finance became an important step in the reform of the budget process in 2002. Thus, scheduling and budget implementation were divided and the processes for strategic, economic and budget planning were consolidated.

In 2005, the Budget Code entered into force (BCRK, 2005). It is a single law governing all financial procedures, starting from budgeting processes and ending with implementation and control. In the budget code, the new principles of the budget system were laid down and pre-existing principles of budget planning and approach to build revenue and expenditure budgets of all levels were radically revised. The formation of mediumterm budget planning was developed, budget execution was ordered and the position of the control system for the budget was strengthened.

In order to harmonize the strategic and budget planning a medium-term fiscal policy was developed, which is a document that defines the fiscal policy in the three-year period. Budget implementation processes were also regulated in more detail and new principles for the budget process were introduced. Budget levels were systematized, with costs at each level, up to the municipal and the regional budgets and the procedures for budget preparation were spelled out in detail. Under the current legislation, only two budget levels, the government and regional ones, were adjusted and any subordinate budgets define the "rules of the game" by themselves. Respective provisions were introduced to ensure transparency and to establish standard requirements for their activities.

\section{Conceptual Importance}

In order to ensure the transparency of the budget of the Republic of Kazakhstan, the accounting and financial reporting structure must keep up the conceptual foundations. The conceptual framework of accounting includes:

- Requirements for the qualitative characteristics of information that is supplied in the financial statements

- Conventions, guidelines and restrictions that are applied in accounting and reporting

The essential features of the accounting information are: Comprehensibility-information must be understandable to users; practicality-information should be useful for decision-making; reliability-information must sum up the phenomena true to fact; neutrality-information must be free of deviations.

Accounting information must meet certain common requirements.

Over the years, the Kazakh government has implemented significant events which provided a positive dynamics in matters of budget transparency. It is the formation of the civil budget, which is designed to familiarize citizens with the basic directions of the state budget.

In addition to the civil section of the budget, a realistic project with the Ministry of Finance in the direction of "Budget Reporting", it is provided to discharge reports on execution of budgets of all levels and analytical information of them on a portal conceptually.

Ministry of Finance infographics are placed for a better perception of the information; the target indicator of the openness of budget execution is defined by the Ministry of Finance in the strategic plan.

International Budget Partnership recommends Kazakhstan to expand opportunities for public participation in budgeting. In particular, according to experts, there is no feedback on the use of public input from both the executives and the legislature.

Since September 2012 a new website of the Ministry of Finance has been launched, which meets the requirements of performance evaluation and now it provides an opportunity to conduct forums with 
discussion of topical issues on the implementation of the budget and the budget priorities of social direction.

Work on the functional section "Civic budget" is being performed, placing all necessary information about the financial performance of the analytical materials relating to the work being done. In particular, according to the methodology changes evaluating the effectiveness of budget management, the state authorities' activities on civil budget will be assessed now.

As can be seen, systematic work allows systematizing the issues of budget execution and evaluation of its openness to the subsequent coverage under the civil budget site of the Ministry of Finance.

\section{Methodology}

As a tool for the evaluation, own method of monitoring, assessment and the country entity on the level of transparency of budgetary data was developed.

The ideological and methodological basis for its development was the methodology of the International Budget Partnership on calculating the Open Budget Index for the countries of the world (1). In developing the methodology the specificity of the budgetary system of the Republic of Kazakhstan was taken into account, which is an extremely important factor.

The budgetary system of the Republic of Kazakhstan is operated in accordance with the Budget Code, adopted in 2008, setting a single basic principle of its organization and functioning.

Fundamentals of the budget process are also regulated by the Budget Code.
Budget classification is applied to prepare and execute budgets in Kazakhstan; the individual components of this classification are common for all budgets and the budgetary system of the country.

Therefore, it is established only at the ideological and methodological levels in connection with the methodology developed by the project of the International Budget Partnership.

\section{The Vertical Layout of Government}

The vertical layouts of the government and local budget internal controls were added. Internal control is conducted by the Financial Supervision Committee of the Ministry of Finance. External control functions were assigned to the Auditing Committee and the Internal Audit Commissions of the regions and cities of republican subordination and the capital. The concept of budgetary investments was expanded; a stepwise selection of investment projects was introduced, as well as the procedure for project performance assessment. Borrowings by local executive authorities in the external and internal capital markets were cancelled with the reservation of drawing rights only from the superior budget.

A new mechanism for funds transfer to the National Fund was entered. In order to effectively implement the objectives of the National Fund a balanced budget method was introduced, taking into account positive experience from around the world. The balanced budget method implemented in the Republic of Kazakhstan is schematically shown in Fig. 1.

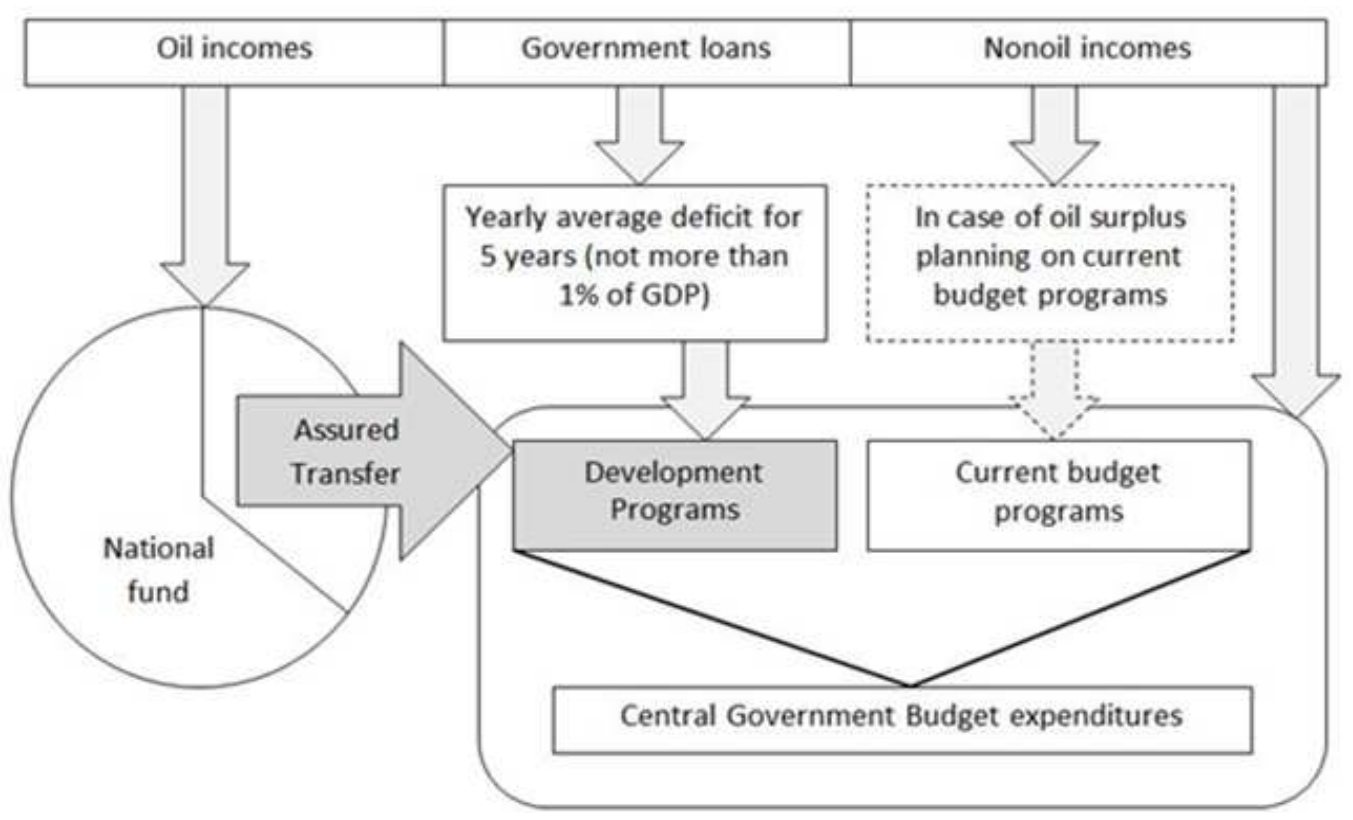

Fig. 1. Effect of a balanced budget method 
Under this method, earnings from oil revenues are fully forwarded to the National Fund. Expenses for the current budget projects are funded by contributions to the national budget from the oil sector of the economy and expenditure financing for low cost development programs is carried out at the expense of the guaranteed transfer from the National Fund, thus, a certain proportion of the expenditure budget can be covered by borrowings (internal and external) within the limits set (Hatry, 2005).

One of the trends of the modern government is to increase its transparency. The Open Government Partnership is the global movement in this direction. The transparent state data on the budget make an important component of the system. Citizens have the right to obtain full, timely and useful information on how the government uses public funds. Moreover, when ordinary people get this information, as well as the skills and opportunities to participate in the discussion of budgetary issues, it contributes to a more effective and efficient use of public funds (Belousov and Timofeyev, 2015).

A new version of the Budget Code was developed in 2007 and in 2009 it was introduced, which made it possible to modernize the budget system (BCRK, 2009). It is based on a 3-year budget, covering key areas such as the role of policy papers and documents in the budget process, the formation of the result-oriented budget programs in accordance with the transition to budget planning, an increase in the budget program administrator's responsibility for the achievement and evaluation of results and the activation of state financial control. The new version of the Budget Code governs all operations in the budget process, from the moment budget proposals made on the basis of strategic directions and goals to the realization of the full assessment of the performance of each public body. Activities of the ministries and agencies were crossed over helping public services. Provisions for the new Budget Code are designed to promote efficiency in using budget funds and government assets. Since early 2010 regular supplements and amendments to the Budget Code have been adopted, relating to the procedures for socio-economic development forecasting, strategic planning of a public body, regulating fiscal relations, targeted transfers, budget investments, quasi-public sector, public services and control of the budget.

\section{Kazakhstan's Position in the International Rankings}

Kazakhstan has drastically improved its figures in the international rankings. Positive outcomes and the recommendations of international experts were discussed at a "round table" meeting on the "Open Budget Index: Improving Transparency and
Accountability", organized by the Soros FoundationKazakhstan and the National Budget Institution Network of Kazakhstan (NBSK) (Artemiev, 2013), deputies from the Majilis, the Auditing Committee on the republican budget implementation control, as well as by the representatives from non-governmental and international organizations.

The Open Budget Index (OBI) evaluates the presence of eight key budget documents, as well as the completeness of their contents and the level of legislature and supreme audit institutions control. In addition, the opportunity of public participation in the budget process is measured.

Table 1 shows the ranking of countries on the budget transparency, New Zealand ranks the first place with 93 points, third place is taken by the UK, the US is ranked the 7th, Russia- the 10th and Kazakhstan is ranked the 47 th with 48 points. It must be said that Kazakhstan should make an effort to improve the budget transparency. For this it seems to be necessary to begin publishing information on the budget, even a small part of it (Klimanov and Mikhailov, 2014).

The index is determined by the "International Budget Partnership" organization once every two years. When the study was conducted back in 2006 for the first time, 59 countries attended and by 2012 there were over 100 countries. Kazakhstan has participated in the process of compiling the Open Budget Index from the beginning and it is consistently improving its ranking.

In 2012, Kazakhstan scored 48 points out of 100 in the Global Budget Openness Index (Fig. 2), which describes the dynamics of change in the Republic of Kazakhstan budget openness index for 2008-2014. International Budget Partnership (OPEN BUDGET INDEX) examined 100 countries, home to $90 \%$ of the world's population. Figure 2 demonstrates that Kazakhstan scored 51 points out of a possible 100 in 2014. In 2008, the Open Budget Index was 35 points, amounting to 38 in 2010, 48 in 2012 and 51 in 2014. As can be seen, the Open Budget Index indicators have been steadily improving its ranking from the start.

Table 1. Ranking of countries on the Open Budget

\begin{tabular}{lll}
\hline Rating position & Country & Score \\
\hline 1 & New Zealand & 93 \\
3 & The UK & 88 \\
7 & The USA & 79 \\
10 & Russia & 74 \\
12 & Brazil & 73 \\
14 & India & 68 \\
25 & Poland & 59 \\
34 & Ukraine & 54 \\
47 & Kazakhstan & 48 \\
58 & Azerbaijan & 42 \\
\hline
\end{tabular}

Compiled by "The Open Budget Converts Life". Open Budget Survey, 2012. www.international-budget.org 
Since then Kazakhstan has improved its score by 10 points and moved into the next group of countries showing a higher degree of public participation in the budget process. Chairman of Soros-Kazakhstan Anton Artemiev said: "This result was made possible thanks to the efficient collaboration of public authorities and non- governmental organizations. Representatives of the NBSK together with the Ministry of Finance developed the first Civilian Budget in the CIS. In addition, such documents as pre-budget statement and annual reports on the results of the government budget implementation were significantly modified" (Artemiev, 2013).

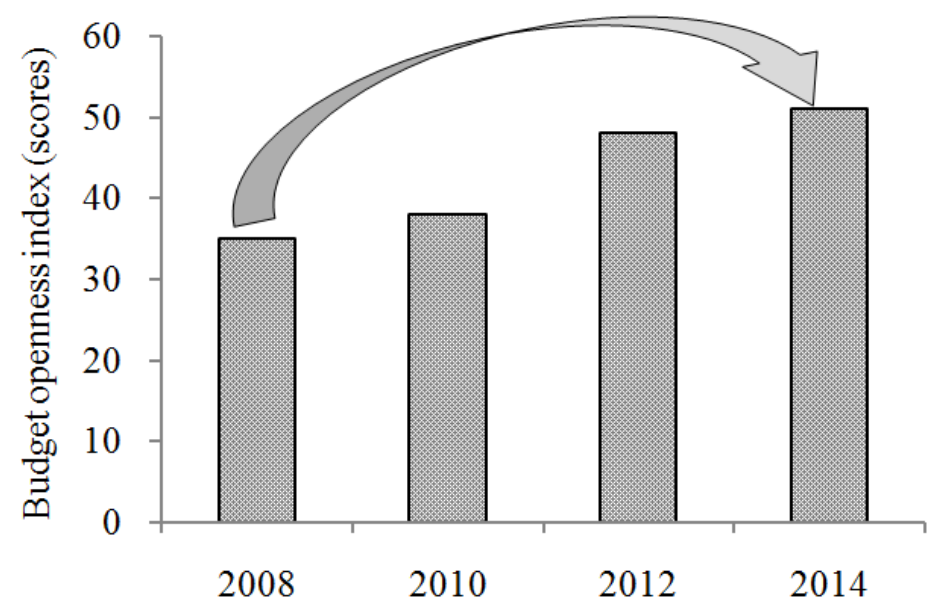

Fig. 2. The Republic of Kazakhstan Open Budget Index Dynamic Pattern for 2010-2014

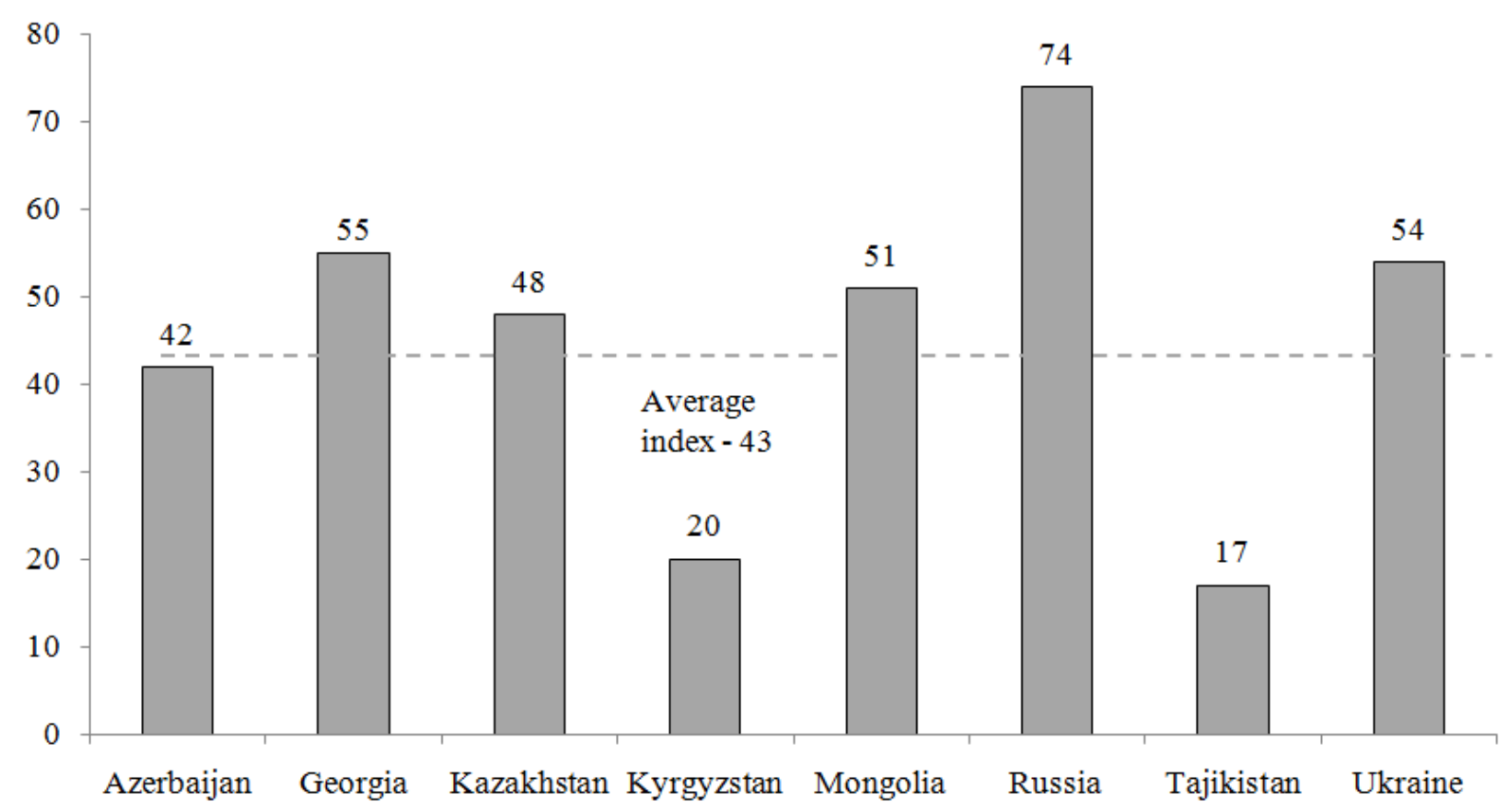

Fig. 3. Open Budget index

During the event recommendations and suggestions were made that allow Kazakhstan to achieve even better results in the index determination in 2014. Kazakhstan's score of 48 points is higher than the average rating of 43 points among the 100 countries analyzed, but it is less than that of the neighboring countries: Russia, Georgia,
Ukraine and Mongolia (Fig. 3). The figure shows the index of budget openness for 2012 in such countries, as Russia, Ukraine, Georgia, Azerbaijan, Kyrgyzstan, Kazakhstan and others. Forty-eight (48) points scored by Kazakhstan for 2012 out of 100 mean that it is above the average among the countries studied, but this figure is 
less than in Russia, Ukraine, Georgia, so it indicates that Kazakhstan society is given only some information about the country's budget.

The points, earned by Kazakhstan, indicate that the government provides society only with limited information about the country's budget and the financial activities of the government for the fiscal year. Therefore, the experts' record states that citizens of the country should set an objective to achieve governmental accountability on public finances control. At the same time, Kazakhstan has significantly improved its result as compared to the Open Budget Index of 2010.

An estimation of the country indicates that the government of Kazakhstan has a potential to significantly increase the budget transparency by introducing a number of short- and medium-term measures, some of which can be achieved at little or no cost to the government. The International Budget Partnership recommends that Kazakhstan should take measures to increase the transparency of the budget, for example, to compile and publish semi-annual reports, to increase the usefulness of the draft budget of executive power, to increase the usefulness of the annual report and to improve the auditor's report quality and the efficiency of the civilian budget by distributing the document through other channels, in addition to the Internet.

According to the experts from the International Budget Partnership, Research Center "Sange", (Dzhandosova, 2013), the executives should conduct active consultations with a large number of legislators in the process of determining budget priorities and the independence of fiscal audit higher authorities should be strengthened: Requiring mandatory consent from the legislative or judicial power to remove a person in charge of the fiscal audit higher authority from the post; the Chief Auditor shall have an authority to conduct independently selected audits in addition to the planned certification audits at the end of the year; the budget of the main body of financial control shall be determined by the Parliament; the level of funding should fully comply with the resources that are required by the main body of financial control for the execution of its mandate.

\section{ROB Background Appearances}

Results-Oriented Budgeting (ROB) is the formation and execution of the budget to achieve concrete results in line with the strategic goals and objectives of the public policy. The basis of this system lies in the main indicators: Measure if you want to manage. Management by objectives, the approach introduced by Peter Drucker as far back as the mid-twentieth century, is increasingly popular in the world. This method has proven effectiveness in completely different structures. Some of its elements have been successfully implemented in public administration of ROB. In fact, it is a financial management by objectives.

ROB allows assessing the performance of public spending in the context of specific programs, as well as seeing and eliminating double or triple functions. Thus, financial resources are allocated to programs and goals, relevant to the public policy (Vershinina, 2014).

The International Budget Partnership recommends Kazakhstan to expand the opportunities for public participation in budgeting, after considering those indicators for which the country has received low ratings. On the same basis as the Open National Budget Index, issues of transparency and accountability at the local level were discussed. After all, two-thirds of the state budget expenditures fall to the local budgets. Basic public services of a social nature, i.e. those of education and health care, are provided exactly there. According to experts, there is a close relationship between the quality of public services rendered and budget expenditures. Determining the degree of transparency for local budgets was made possible by the "Open National Budget Index" developed in 2010 by the National Budget Institution Network of Kazakhstan.

The director of the Institute for Local SelfGovernment Sergey Khudyakov (2013) explains: "Indices of the regions of Kazakhstan allow not only detecting differences in budgetary processes throughout the country, but also motivating local authorities to improve the transparency of information and to improve the efficiency of budgetary spending. This index also enables to identify which regions provide more opportunities for their citizens to participate in the budget process". Continuing the theme of local budgets, Chairman of the Audit Committee Oksikbayev (2012) pointed out that "Criminal liability should be applied for undisbursed public money". According to him, on average today, 30-50 billion Tenges (KZT) a year remain unused in our country, while other countries save on almost everything. As the deputy explained, an undisbursed budget covers, first of all, kindergartens, schools, new roads and drinking water and whereas the process for the formation of the Republican government budget has become more transparent, its performance in the regions still remains a mystery.

The deputy said that there is no budget hierarchy. Therefore, at the local level the flow of public money is not being tracked. This is a big failure of the executives. Oksikbayev (2014) highlighted that "unfortunately, those who form the budget request today, do not take any responsibility if they request justified or unjustified figures. It is necessary even to make it a criminal offence".

Vice Minister of Finance Ruslan Dalenov agreed that serious work on the part of the Ministry of Finance was being done, especially in the expansion of the theme "Civil budget". As a result, materials have become more 
accessible to the understanding of a wide range of the Internet users. But there are still questions that the ministry is working on. So, the plans of the ministry are to make available, on a website, some of the questions asked during the discussion of the Report on the budget implementation in the Parliament and the answers to them and then to post public debt monitoring and other materials. In addition, R. Dalenov talked about the need to develop a draft bill on budget transparency.

All parties concerned with improving the situation took note of the information. Issues, seeking decisions, are exactly specified. Some issues still remain to be implemented.

\section{Discussion}

This report examines the transparency and openness of the budget of the Republic of Kazakhstan. The question posed in this article is how to improve the openness of budgets in the country, which will reduce the level of corruption and give the public opportunities to participate in government.

The Open Budget Survey has been analyzed by IBP (International Budget Partnership, IBP) every two years since 2006. In 2012, the number of countries covered by the study reached up to one hundred (100). Open Budget Index of Kazakhstan is held by $\mathrm{Zh}$. Dzhandosova (Research Center "Sange") and also by the Department of Reporting of the Government Finance Statistics of MF $\mathrm{RK}$, in the country this figure improved from 35 points in 2008 to 38 in 2010 and increased up to 48 in 2012 and to 51 points in 2014 (Dzhandosova, 2013).

As noted by scholars and practitioners, in particular by O.Oksikbaev, a Majilis deputy, who emphasizes that having supervised Accounts Committee during 10 years, he became acquainted with the experience of other countries where market mechanisms and control of the effective use of the budget are very tight with a focus on ensuring its use of full transparency.

However, in our country there is no full transparency of the budget, MF and other bodies are working on this issue, even though our country is the only CIS country which publishes the civil report.

In our republic a semi-annual report is more similar to the current report for the six months, it seems that here we need an explanation of factors that influence the approved budget; also it is necessary to increase the usefulness of the annual report, explaining the difference between forecast figures and actual results of macroeconomic indicators.

This study will be the impetus for the improvement of the budget and it will increase the budget transparency in the Republic of Kazakhstan, which will reduce the level of corruption in the government and will connect the resources and strategic priorities. The openness of the budget will allow the government to maneuver public debt (obtaining foreign loans at lower interest rates and allow raising the level of public confidence in the government) (Oksikbayev, 2014).

\section{Conclusion}

Having examined the current situation of the budget system development in the Republic of Kazakhstan, as well as having analyzed the participation in the process of compiling the Open Budget Index, a conclusion may be drawn that it is necessary to improve the rating to further enhance the openness and transparency of the budget from the very beginning.

In recent years, there is a tendency in the Republic of Kazakhstan to increase the obligations of the state, as an increase in operating costs. In general, the expenses of the government budget increased from $59.6 \%$ in 2005 to $81.1 \%$ in 2013 . On this basis, it is necessary to reduce the budget of dependency and "running costs" in the total expenditures of the government budget. Furthermore, the annual growth of the government budget must be accompanied by an increase in efficiency. It is necessary to improve the system of performance assessment for local authorities, since currently existing assessment systems are not intended to encourage an achievement of high results.

The development of the budget process, in accordance with the emerging requirements in the methodology and practice of budget management, indicate the need for further improvements in the legislation of the Republic of Kazakhstan. Parallel to this are some issues which require further development. For example, up to the present moment, the common evaluation of budget use is based rather on the development of the budget than on the results achieved. Significant amounts of non-targeted use of the budget suggest that they require improvement and amendment to the articles in the Budget Code, defining the concept of the budget offense article and key responsibilities for them, as well as the respect of the budget legislation requirements by all participants of the budget process.

As noted above, in 2012 Kazakhstan scored 48 points out of 100 in the global Open Budget Index. To improve the transparency of the index in the future, Kazakhstan should achieve the accountability of the government during the fiscal year. The Republic of Kazakhstan should take measures to increase the budget transparency, for example, by compiling and publishing semi-annual reports, to increase the usefulness of the draft budget of executive power and of the annual reports and to improve the auditor's report quality and the efficiency of the civilian budget by distributing the document through other channels, in addition via the Internet. 
It is known that two thirds of the government budget expenditures fall on the local budgets, so it is necessary to pay greater attention to the budget transparency at a regional level. It is required to reduce undisbursed state money and to bring to trial those who are responsible for the undisbursed budget.

\section{Acknowledgement}

We thank our unknown reviewers for their review and comments that greatly improved the manuscript.

\section{Author's Contributions}

Kuralay Berkinovna Issatayeva: Developed the conceptual idea and design of the research work.

Ainagul Amangeldinovna Adambekova: Arranged questionnaire survey, participated in the results analysis, contributed to the drafting of the article.

\section{Ethics}

This article is original and contains unpublished materials. The corresponding author confirms that all of the other authors have read and approved the manuscript and there are no ethical issues involved.

\section{References}

Artemiev, A., 2013. Budget becomes more open. Finansist Kazakhstana, 3: 27-22.

BCRK, 2005. Budget code of the republic of Kazakhstan.
BCRK, 2009. Budget code of the republic of Kazakhstan.

Belousov, I. and O. Timofeyev, 2015. Methodology and results of the study of budget data transparence level in the Russian Federation. Finances, 3: 12-12.

CRK, 1995. Constitution of the Republic of Kazakhstan.

Dzhandosova, Z., 2013. Open budget is a necessary condition for development of country. Finances Kazakhstan, 4: 28-28.

Hatry, T.P., 2005. Performance measurement: Getting results/Translation from English. Fund "City Economics Institute" Moscow.

Khudyakov, S., 2013. Budget becomes more open. Finances Kazakhstan, 3: 27-27.

Klimanov, V.V. and A.A. Mikhailov, 2014. Openness and transparency of the Russian budget in the global dimension. Finances, 7: 15-15.

LBS, 1991. Law "on the budget system.

LBS, 1999. Law "on the budget system.

LBS, 1996. Law "on the budget system".

Oksikbayev, O., 2012. Financial discipline should not be liable floor. Kazakhstanskaya Pravda, 20: 12-12.

Oksikbayev, O., 2014. Report of the government of Kazakhstan and of the accounts committee for 2014. Astana.

Vershinina, K., 2014. Not just learn, but achieve results, or how future budget planning will change Kazakhstan. Finances, 6: 42-42.

Zhunusova, R.M., A.K. Zhusupova and G.B. Utibayeva, 2014. Budget planning and forecasting. Economics. 